\title{
PERSEPSI PERAWAT TERHADAP PRINSIP-PRINSIP ETIK DALAM PELAKSANAAN TINDAKAN KEPERAWATAN DI ICU RUMAH SAKIT TK. II PUTRI HIJAU MEDAN
}

\section{Nurse Perceptions of Principles of Conduct in The Implementation of Action in ICU Nursing Home Sick At Putri Hijau Hospital Medan}

\author{
Resmi Pangaribuan \\ Dosen Tetap Yayasan Akper Kesdam I/BB Medan \\ email: resmi.pangaribuan@yahoo.co.id
}

\begin{abstract}
The nursing ethics were value and principles trusted by the nursing profession in carring out their duties related to the patient with society, the relationship between nurses and mates included the organization of the profession, as well as the regulation of nursing practice it self. The nurse perception to the ethical principles was able to influence the behavior of a nurse in making decision of nursing action. The aim of this observation is to explore the nurse perception to the ethichal principlesin implementation nursing action at Intensive Care Unit level II Putri Hijau Hospital Medan, this observation was done to nurse with four respondents. The method of phenomenological qualitative. The sample with purposive sampling. Data was collected nursing indepth interview and then recorded by tape recorder. The results of observation reflected from six themes appearing which were agreed in doing treatment. Patient or patient's family have right to refuse the treatment by giving sign of non-consent letter, to appreciate the patient and the family using traditional ways, tot the useful, and avoiding the dangerous thing to the patient. Religion teaches good deeds, never different patients, and to take early treatment in accordance with the cases priority, give complete information.
\end{abstract}

The conclusion of this observation was glance perception of nurses in implementing the nursing treatment.

Key words: The Nursing's perception, Ethichal principles, Nursing action

\section{Pendahuluan}

Etika merupakan pedoman untuk melakukan apa yang seharusnya dilakukan dan merupakan kesepakatan dari nilai-nilai positif untuk menghasilkan kebaikan guna perkembangan individu dan masyarakat, dan aturan apa saja yang kita butuhkan untuk mencegah manusia berbuat jahat (Suhaemi, 2003). Etika keperawatan adalah nilai-nilai dan prinsip-prinsip yang diyakini oleh profesi keperawatan dalam melaksanakan tugasnya yang berhubungan dengan pasien, masyarakat, teman sejawat maupun dengan organisasi profesi, dan juga dalam pengaturan praktik keperawatan itu sendiri. Prinsip-prinsip etika ini oleh profesi keperawatan secara formal dituangkan dalam suatu kode etik yang merupakan komitmen profesi keperawatan akan tanggung jawab dan kepercayaan yang diberikan oleh masyarakat (Berger \& Williams, 1999).

Sri Lestari (2004) melaporkan bahwa persepsi perawat terhadap prinsip-prinsip etika

meliputi agama mengajarkan manusia untuk berbuat baik, tidak membedakan, mendapatkan persetujuan melakukan tindakan, pasien atau keluarga pasien berhak menolak tindakan, mendahulukan tindakan sesuai dengan prioritas masalah, melakukan tindakan untuk kebaikan, menghindari hal-hal yang membahayakan pasien, menghargai pasien dan keluarga yang menggunakan cara-cara tradisional.
Di unit perawatan Intensive Care Unit (ICU) Rumah Sakit TK II Putri Hijau Medan, metode asuhan keperawatan yang diberikan adalah menggunakan pendekatan total care. Dari hasil survei pendahuluan terdapat beberapa perawat yang kurang memperhatikan akibat yang mungkin timbul dari tindakan yang tidak sesuai dengan prosedur. Disamping memberikan pelayanan yang bersifat khusus karena kondisi pasien yang kritis, perawat ICU juga sering menghadapi kejadian yang memerlukan pertimbangan khusus terutama saat menghadapi situasi yang sulit atau bahkan dilema etik dari pasien yang dirawatnya.

Dalam hal ini etik autonomy, seorang pasien yang baru selesai menjalani operasi craniotomie dan langsung dibawa ke ruang perawatan ICU, perawat langsung memberikan pertolongan langsung misalnya memberikan terapi sesuai dengan kebutuhan pasien tanpa memberitahukan keluarga pasien tentang tindakan yang diberikan apakah keluarga pasien setuju atau tidak setuju akan tindakan yang diberikan kepada pasien.

Pinsip non-maleficence dan beneficence (tidak mencederai/melukai pasien dan memberikan manfaat) yaitu pada pasien yang ada di ICU mayoritas tidak sadar dan gelisah maka dipasang restrein, pada pemasangan restrein mengakibatkan luka lecet pada kulit pasien yang dapat mengakibatkan kerugian bagi pasien. Pada pemberian tindakan penyedotan lendir (suction) dari satu pasien ke pasien yang lain yang dapat 
mengakibatkan terjadinya infeksi silang kepada pasien kepada pasien yang satu lagi dan dapat mengakibatkan munculnya penyakit baru. Prinsip justice (keadilan) apabila ada keluarga salah satu dari anggota yang bekerja di rumah sakit tersebut perawatannya berbeda dengan pasien lain dan segala administrasi di dalamnya akan sangat mudah padahal perawat harus berlaku adil dalam memberikan pelayanan keperawatan dengan tidak membedakan status sosial dan ekonominya akan tetapi pelayanan keperawatan diberikan sesuai dengan kebutuhan dan keselamatan jiwa si pasien. Prinsip veracity (kejujuran), pada kondisi pasien yang mengalami krisis atau pada tahap terminal perawat tidak mengatakan hal yang sesungguhnya kepada keluarga pasien sehingga dapat menimbulkan konflik antara perawat dengan keluarga pasien. Seharusnya perawat harus mengatakan yang sejujurnya pada keluarga tentang kondisi pasien yang sebenarnya. Prinsip confidentiality (mempertahankan kerahasiaan), perawat harus menjalin hubungan yang baik dengan pasien maupun keluarganya, misalnya apabila pasien ataupun keluarga pasien menanyakan tentang tindakan yang diberikan maka perawat harus memberikan keterangan yang tepat dan menjalin suatu hubungan yang baik sehingga ada rasa saling percaya antara perawat dengan pasien. Perawat harus memikul sumpah dan kewajiban dari profesinya, misalnya keluarga pasien menceritakan hal-hal pribadi yang menyangkut pasien yang dirawat kepada perawat disini perawat harus merahasiakan ini hal penting ini dari orang lain kecuali diminta keterangan yang lebih lanjut demi keselamatan pasien. Prinsip fidelity (keyakinan) dimana ada keluarga pasien yang menggunakan obat-obat tradisional, hal ini cenderung dilarang perawat karena alasan akan menimbulkan bau yang tidak enak pada ruangan dan pasien itu sendiri.

Dengan ini penulis tertarik ingin meneliti tentang persepsi perawat terhadap prinsip-prinsip etika dalam pelaksanaan tindakan keperawatan di ICU Rumah sakit TK. II Putri Hijau Medan.

\section{Perumusan Masalah}

Berdasarkan uraian di atas maka rumusan masalahnya adalah bagaimana persepsi perawat terhadap prinsip-prinsip etik dalam pelaksanaan tindakan di ICU Rumah sakit TK.II Putri Hijau Medan tahun 2010?

\section{Tujuan Penelitian}

Untuk mengeksplorasi persepsi perawat terhadap prinsip-prinsip etik dalam pelaksanaan tindakan di ICU Rumah sakit Tk. II Putri Hijau Medan

\section{Manfaat}

1. Bagi Rumah Sakit
Sebagai masukan bagi rumah sakit dalam melaksanakan prinsip etika keperawatan di dalam melaksanakan tindakan keperawa-tan kepada pasien.

2. Bagi Perawat

Hasil penelitian ini diharapkan dapat digunakan sebagai masukan dalam memberikan asuhan keperawatan secara komprehensif dan holistik pada pasien dengan memperhatikan teori dan prinsip etika

\section{Metode Penelitian}

Jenis penelitian yang dilakukan adalah deskriptif dengan pendekatan kualitatif fenomenologi. Penelitian kualitatif adalah penelitian yang bermaksud untuk memahami fenomena tentang hal yang dialami subyek penelitian misalnya perilaku, persepsi, motivasi, atau tindakan yang dilihat secara menyeluruh dan dengan cara deskripsi dalam bentuk kata-kata dan bahasa dalam konteks khusus yang alamiah dengan menggunakan berbagai metode alamiah (Moleong, 2002).

Adapun yang yang menjadi populasi pada penelitian ini adalah seluruh perawat yang bekerja di ruang ICU Rumah Sakit Tk. II Putri Hijau Medan sebanyak 12 orang.

Besar sampel dalam penelitian ini adalah 4 orang yang diambil secara purposive sampling (sampling bertujuan) dengan kriteria perawat yang bekerja di ICU Rumah sakit TK. II Putri Hijau Medan, pendidikan D-III Keperawatan, usia 25-30 tahun, masa kerja minimal 2-3 tahun, dan bersedia menjadi responden

Instrumen penelitian ini adalah 1.Kuesioner data demografi yang berisi pertanyaan mengenai data umum responden pada lember pengumpulan data, 2. Panduan wawancara mendalam dengan mengikuti petunjuk wawancara.

Data dikumpulkan dengan tehnik wawancara mendalam (in-depth interview), pewawancara memiliki daftar pertanyaan yang disiapkan dan diyakini dapat menjadi semacam format untuk jawaban responden berkaitan dengan proyek peneliti, mencatat jawabannya atau merekamnya dengan alat perekam. Hasil rekaman didengarkan kembali kemudian diketik dan dibuat transkripnya dalam bentuk verbatim (kata demi kata) ditambah dengan catatan lapangan.

Analisa data dalam penelitian ini, peneliti mengolah dan mengorganisasikan data yang diperoleh melalui catatan lapangan, hasil rekaman dan transkrip wawancara

\section{Hasil dan Pembahasan}

Hasil wawancara

Komponen prinsip-prinsip etika yang diteliti adalah prinsip autonomy, non maleficence, beneficence, justice, veracity, confidentiality, fidelity. Biodata respon tersebut adalah: Responden I memiliki jenjang pendidikan D-III Keperawatan, 
memiliki masa kerja di ICU selama 4 tahun, responden menganut agama Katholik, dan suku Batak. Responden II memiliki jenjang pendidikan D III Keperawatan, memiliki masa kerja di ICU selama 4 tahun, responden menganut agama Islam dan suku Jawa. Responden III memiliki jenjang pendidikan D III Keperawatan, memiliki masa kerja di ICU selama 5 tahun, responden menganut agama Kristen Katholik dan suku Batak. Responden IV, memiliki jenjang pendidikan D III Keperawatan, memiliki masa kerja di ICU selama 4,5 tahun, responden menganut agama Kristen Protestan dan suku Batak.

Tema yang muncul tentang persepsi perawat terhadap prinsip-prinsip etika dalam tindakan keperawatan

Dari hasil wawancara dengan empat orang responden, keenam tema tersebut adalah:

1. Mendapatkan persetujuan dalam melakukan tindakan dan pasien atau keluarga pasien berhak menolak tindakan dengan menandatangani pernyataan penolakan tindakan.

\section{Responden I}

“.......Pandangan saya sebagai seorang perawat apabila keluarga pasien menolak atau tidak setuju terhadap tindakan keperawatan atau medis yang kita lakukan terhadap pasien itu adalah hak pasien suatu misal dengan pasien trauma capitis yang masuk tadi perlu penanganan secara cepat dilakukan tindakan suatu misal scaning untuk mengetahui adanya perdarahan atas anjuran dokter dan apabila terjadi perdarahan perlu dilakukan tindakan operasi yaitu craniotomie yang sudah terlebih dahulu dianjurkan oleh dokter yang menangani pasien maka perlu kita tanyakan apakah pasien setuju atau tidak setuju dilakukan tindakan operasi kalu tidak setuju itu hak keluarga atau pasien".

\section{Responden II}

“.....ya, kalau si pasien atau keluarga pasien menolak pemberian terapi maka kita menyetujuinya karena itu hak pasien untuk menolak tindakan yang kita lakukan walau kita tau itu penting, darurat, emergensi yang harus diberikan kepada pasien tersebut. Ya ...demi ini diantara perawat, dan sikeluarga pasien memang ada prosedurnya setiap apapun tindakan yang akan kita berikan wajib diberitahukan kepada pasien atau keluarga bisa menolaknya.

\section{Responden III}

“....apabila pasien atau keluarga pasien tidak menyetujui tindakan tersebut kita harus memberikan penjelasan kepada pasien terhadap tindakan yang kita laksanakan kalau pasien tidak setuju kita tidak boleh memaksa, kalau toh setelah diberi keterangan menolak ya...kita harus terima. Contoh, kita kasi suatu berupa administrasi yang bisa ditandatangani kalau tidak setuju karena kalau sudah ada persetujuan tidak mau dilakukan tindakan kita sudah ada pegangan karena suatu hari keluarga menuntut kita sudah ada bukti”.

\section{Responden IV}

“.....kita beri informasi jadi kalau pasien juga menolak kita harus menghargai pendapat tersebut yang penting kita sudah beri informasi kalau nggak mau ya udah. Yang dapat menentukan suatu tindakan itu ya kita mendapat persetujuan dari pasien kalau tidak setuju jangan jangan dilakukan kita tidak bisa memaksa karena itu hak pasien".

Pasien atau keluarga pasien berhak menolak tindakan dengan menandatangani PernyataanPenolakan

\section{Responden I}

“....Kalau pasien atau keluarga tidak setuju terhadap tindakan yang diberikan itu hak keluarga pasien yang penting kita sebagai seorang perawat sudah memberikan informasi yang jelas kepada keluarga pasien".

\section{Responden II}

“....sebelum kita memberikan terapi kita beritahukan dulu. Salah satu contoh kecil dalam pemberian infus, mungkin sekali cucuk tidak dapat kemudian harus dicucuk lagi dan kita beri penjelasan bahwa infus itu penting, jika pasien menolak kita berikan SIO, surat persetujuan jadi jika ada sesuatu terjadi kita bisa pertanggung jawabkan ke depan”.

\section{Responden III}

“....Contoh, kita kasi suatu berupa administrasi yang bisa ditandatangani kalau tidak setujukarena sudah ada persetujuan tidak mau dilakukan tindakan kita sudah ada pegangan karena suatu hari keluarga menuntut kita sudah ada bukti".

\section{Responden IV}

“...sewaktu dia menolak kita harus beri dia SIO dan harus ditandatangani tetapi kita beri penjelasan dulu”.

2. Melakukan tindakan untuk kebaikan, menghindari hal yang membahayakan

\section{Responden I}

“....sebagai seorang perawat kita harus memberikan pelayanan yang baik terhadap pasien yaitudengan memberikan informasi yang tepat, mencegah infeksi, mencegah terjadinya cedera dan juga harus serta menerapkan sapa, sentuh, dan memberikan perhatian kepada pasien sehingga pasien merasa diperhatikan dengan apa yang kita berikan. Kita harus cuci tangan terlebih dahulusetelah kita memegang pasien apabila perlu menggunakan hanscoen 
apabila menggunakan alat suntik kepada pasien cukup hanya sekali pakai kemudian dibuang untuk mencegah infeksi silang baik dari perawat ke pasien maupun dari alat ke pasien. Sebagai seorang perawat harus perlu pemantauan setiap waktu dan setiap jam agar tidak terjadi kecelakaan yang bisa menghilangkan nyawa pasien dan harus menggunakan alat yang steril dan meminimalakan terjadinya dekubitus maka pasien perlu kita rawat dengan baik”.

\section{Responden II}

“...Contoh kecil,masalah pemasangan kateter ikutan sesuai dengan prosedur tiga hari sekali itu biasanya kita ganti kateternya dengan yang baru untuk mencegah infeksi.Kemudian masalah penyangga tempat tidur kadang pasien di ICU ini gelisah,coma, tidak semua pasien composmentis, itu harus kita perhatikan.Untuk mencegah terjadinya infeksi dengan adanya pembatasan pengunjung dan untuk memasuki ruangan tidak boleh memakai baju khusus dan tentang alat-alat yang kita gunakan harus kita perhatikan kesterilan alatnya”.

\section{Responden III}

“...Kita harus melakukan tindakan dengan hatihati dan sungguh-sungguh kepada pasien jangan sampai terjadi decubitus seperti pasien di ICU ini akan bedrest minimal sekali empat jam dimiringkan terus kita harus lebih teliti melihat kondisi pasien dan pasien iti tidak bisa bilang apa yang dirasakan karena tidak semua kondisi pasien itu baik dan juga kita harus menjaga kesterilan alat yang kita gunakan kepada pasien itu”.

\section{Responden IV}

“...Dalam pelaksanaan keperawatan kita harus melaksanakan yang terbaik bagi pasien.Sebagai seorang perawat kita harus hati-hati melakukan tindakan sehingga jangan pasien merasa dirugikan misalnya sebelum dan sesudah melakukan tindakan kita harus mencuci tangan untuk menghindari terjadinya infeksi dan kita menghindari infeksi penyakit pasien terhadap kita.Kalau pake jarum suntik sekali pake buang jangan berulang-ulang,kalau memasang kateter harus dengan hati-hati jangan sampai terjadi infeksi pada saluran kemihnya,dan penyangga tempat tidur jangan pasien sampai terjatuh gara-gara penyangga tempat tidur sudah rusak dan tidak layak pakai.Pasien disinikan ratarata tidak sadar dan pada saat mensuction jangan sampai kita jolok-jolok yang dapat menyebabkan iritasi kan merugikan pasien,decubitus juga rajin kita miringmiringkan, jangan dia datang jadi decubitus karena kita malas memiringkan dan plebitis juga jangan terjadi, plebitis juga jangan infus sampai satu minggu atau dua minggu tidak kita ganti akhirnya demam”.

\section{Agama Mengajarkan berbuat Baik}

Sumber agama merupakan dasar dalam memberikan pelayanan kepada pasien. Hal itu berarti bahwa berbuat baik dianggap melaksanakan perintah Tuhan, dimana perintah tersebut dianggap sebagai moral yang baik dan benar. Berikut pernyataan responden tentang agama mengajarkan berbuat baik.

\section{Responden I}

“...Kita harus menganggap pasien itu seperti keluarga kita untuk kita jaga dan juga kita kasihi seperti yang diajarkan oleh agama lagian manusia itu sama dihadapkan Tuhan".

\section{Responden II}

“...bila kita merawat pasien dengan cinta dan kasih sayang itu merupakan bagian dari iman untuk melayani sesama yang memerlukan pertolongan kita, dalam agama juga kita diajarkan kita sesama manusia harus tolong menolong, menghargai. Didalam ajaran agama muslim menolong sesama itu adalah Ibadah, dan semua agama mengajarkannya jadi kita sebagai seorang perawat memang kewajiban kita menolong pasien dengan kasih sayang dan kita mendapat pahal kedepannya".

\section{Responden III}

“...Kita harus merawat pasien itu dengan kasih melayani sesama yang memerlukan, ya..dalam agama kita harus menolong sesama dengan iklas".

\section{Responden IV}

“...Sebagai seorang perawat itu kita harus merawat pasien dengan kasih, ikhlas, jadi dalam melaksanakan tindakan itu kita harus berdasarkan kasih dan dalam agama juga diajarkan salingtolong menolong dan menghargai sesama manusia dan lagian kita berbuat baik itu menambah pahala”.

4. Tidak Membeda-bedakan pasien dan mendahulukan tindakan sesuai prioritas masalah

Dalam konteks ini prinsip justice (keadilan) ditetapkan yaitu tidak membedakan-bedakan pasien, dan memastikan pasien mendapat apa yang seharusnya didapatkan. Dengan melakukan prioritas tindakan dengan tepat maka dapat pula terdeteksi adanya suatu masalah lebih dini sehingga dapat mencegah terjadinya kondisi yang lebih buruk atau menghindari terjadinya hal yang membahayakan.

Berikut pernyataan responden tentang tidak membeda-bedakan pasien:

\section{Responden I}

“...Dalam merawat pasien kita harus berlaku adil terhadap pasien dengan memandang 
pasien itu sebagai keluarga kita sendiri yang harus kita jaga dan kita rawat dan perlu kita hormati, kita kasihi dengan tulus iklas baik kaya atau miskin ataupun berbeda agama karena semua manusia dihadapan Tuhan sama".

\section{Responden II}

“...Dimana- mana memang kita harus berlaku adil, ya apalagi terhadap pasien, dalam merawat pasien kita tidak boleh membedakan pasien itu kaya, miskin, suku, aliran kepercayaan itu tidak boleh. Saya merawat pasien itu sebagai orang dengan memandang pasien itu dengan memandang pasien itu orang yang betul-betul membutuhkan pertolongan, kita hormati pasien sebagai orang yang bermartabat yang sama dihadapan Tuhan yang saya sarankan seperti saat ini dengan penggunaan Jankesmas perawat yang kita beriakn sam dengan orang yang bisa bayar perawatan dengan penuh jadi kita tidak boleh membeda-bedakannya".

\section{Responden III}

“...Kita merawat pasien tidak bisa membedabedakan pasien itu kaya atau miskin suku atau aliran manapun, ya kita sebagai perawat harus betul-betul merawat pasien itu karena kita itu sama-sama diciptakan Tuhan”.

\section{Responden IV}

“...Kita harus melakukan tindakan itu sebaiknya kita tidak melihat status pasien itu apalagi seperti di Rumah Sakit Putri Hijau ini sangat jelas penggunaan Jankesmas dan juga kalau status yang bisa bayar penuh kita jangan lansung servis habis.

\section{Mendahulukan tindakan sesuai prioritas} masalah

Berikut pernyataan perawat tentang mendahulukan tindakan sesuai prioritas masalah.

\section{Responden III}

“... Dalam merawat pasien kita harus dapat membedakan dan memprioritaskan masalah maksudnya kita memprioritaskannya sesuai dengan kebutuhannya yang jelasnya penanganan yang emergensi dulu itu intinya".

1. Memberikan informasi dan mempertahankan kerahasiaan

Prinsip ini merupakan prinsip confidentialy dan juga veracity dan ini harus dimiliki oleh perawat. Berikut pernyataan responden tentang veracity tersebut

\section{Responden I}

"Kita harus menjelaskan tentang tindakan apapun yang kita lakukan demi kesembuhan dokter atau perawat, disamping itu juga dengan menjelaskan tindakan apa yang diberikan diharapkan kerja sama yang baik antara tim medis dengan keluarga pasien demi kesembuhan pasien tersebut".

\section{Responden II}

"Yah.. kita tetap akan beritahu tentang kondisi pasien apalagi pasien sudah pada tahap terminal kita harus lebih hati-hati lagi dengan kata lain kita tidak perlu menutup-nutupi kondisi si pasien karena keluarga perlu mempersiapkan segala sesuatunya untuk menghadapi kondisi si pasien tersebut'.

\section{Responden III}

"Pastinya kita memberitahukan keluarga bahwa kondisi pasien sudah pada tahap terminal, gimanapun kondisi pasien harus diberitahu karena kalau ada apa - apa kita juga nantinya yang disalahkan".

Berikut pernyataan responden tentang confidentially

\section{Responden III}

"Pastinya kita memberitahukan keluarga bahwa kondisi pasien sudah pada tahap terminal,gimanapun kondisi pasien harus diberitahu karena kalau ada apa - apa kita juga nantinya yang disalahkan. Memang kita sebagai seorang perawat kita harus menjaga kerahasiaan pasien salah satunya tidak menceritakan kepada pasien dengan tidak menceritakn penyakit pasien kepada oarang lain tentang apa penyakit pasien karena didalam sumpah perawat ada tertulis segala kerahasiaan pasien tidak boleh diceritakan kepada oarang lain kecuali diperlukan oleh hukum".

\section{Responden IV}

“...Saya sebagai seorang perawat ada kalanya kita perlu memberitahukan sesuatu kepada orang lain tapi ada kalanya kita tidak perlu menceritakan sesuatu/kerahasiaan pasien kepada orang lain, jadi kesimpulannya kita tidak boleh menceritakan kerahasiaan kepada orang lain".

6. Menghargai pasien atau keluarga yang menggunakan cara-cara tradisional

Dengan menghormati budaya pasien ini juga diperlukan sikap menerima pasien apa adanya, sehingga meskipun perawat tidak sepaham dngan budaya pasien tetapi tetap menghormatinya sebagai bagian dari diri pasien. Berikut pernyataan responden tentang menghargai pasien atau keluarga yang menggunakan cara-cara tradisional .

\section{Responden III :}

“...Kalau ada pasien atau keluarga yang meminta untuk menggunakan obat tradisional itu hak pasien. Jadi hak pasien untuk mempercayai obat tradisional, misalnya air yang diberi doa, kia tidak bisa menghalangi 
selama itu tidak mengganggu perawatan dan terapi medis, itu boleh - boleh aja”.

\section{Responden IV}

“...kia harus menghargai pasien atau keluarga yang menggunakan obat - obat tradisional selagi itu tidak menggangu perawatan ya sahsah saja."

\section{Pembahasan}

Diskusi tema yang didapatkan berdasarkan hasil penelitian yang dilakukan pada empar orang responden tentang persepsi perawat terhadap prinsip-prinsip etika dalam pelaksanaan tindakan keperawatan, didapatkan data yang menunjukkan bahwa sebagian besar persepsi perawat mencerminkan penerapan beberapa prinsip-prinsip dan teori etika dalam pelaksanaan tindakan. Hal ini diperjelas dengan teidentifikasinya tema-tema dominan yang muncul. Pembahasan tema tersebut adalah sebagai berikut:

1. Mendapatkan persetujuan dalam melakukan tindakan dan pasien atau keluarga pasien berhak menolak tindakan dengan menandatangani pernyataan penolakan tindakan.

Prinsip tersebut merupakan prinsip perawat saat akan melakukan suatu tindaka. Sebelum melakukan tindakan, perawat harus memberitahukan tindakan yang akan dilakukan kepada pasien. Hal ini sesuai dengan prinsip menghargai pasien sebagai orang yang bermartabat dan mampu untuk menentukan apa yang terbaik bagi dirinya sendiri (Autonomy)

Berikut pernyataan responden tersebut:

“....apabila pasien atau keluarga pasien tidak menyetujui tindakan tersebut kita harus memberikan penjelasan kepada pasien terhadap tindakan yang kita laksanakan kalau pasien tidak setuju kita tidak boleh memaksa, kalau toh setelah diberi keterangan menolak ya...kita harus terima. Contoh, kita kasi suatu berupa administrasi yang bisa ditandatangani kalau tidak setuju karena kalau sudah ada persetujuan tidak mau dilakukan tindakan kita sudah ada pegangan karena suatu hari keluarga menuntut kita sudah ada bukti”.

Pasien atau keluarga pasien berhak menolak tindakan dengan menanda-tangani Pernyataan Penolakan

Hal ini sesuai dengan prinsip menghormati pribadi yang mempunyai otonomi. Sebagai individu, disamping bebas menentukan atau memilih tindakan yang akan dilakukan, maka pasien atau keluarga berhak pula menolak suatu tindakan yang akan dilakukan kepadanya. Dalam melaksanakan suatu tindakan, maka tidakboleh memaksakan kepada orang lain. Karena memaksakan sesuatu kepada orang lain berarti mengabaikan martabatnya sebagai manusiayang sanggup untuk mengambil sikapnya sendiri (Suseno, 1997). Pada dasarnya hal ini merupakan pelaksanaan prinsip autonomy (kebebasan untuk menentukan diri sendiri)yang dalam bentuk nyatanya adalah pemberian informed consent. Pada pemberian informed consent ini maka perawat memberi penjelasan dengan lengkap dengan cara yang dapat dimengerti oleh pasien, tanpa adanya tendensi lain. Informasi yang diberikan sematamata agar pasien atau keluarga mengerti tentang prosedur dari suatu tindakan, mampu mencernadengan baik informasi yang diberikan, dan akhirnya dapat mampu mengambil keputusan yang sesuai dengan yang mereka inginkan. Berikut pernyataan responden tersebut:

“....sebelum kita memberikan terapi kita beritahukan dulu. Salah satu contoh kecil dalam pemberian infus, mungkin sekali cucuk tidak dapat kemudian harus dicucuk lagi dan kita beri penjelasan bahwa infus itu penting, jika pasien menolak kita berikan SIO, surat persetujuan jadi jika ada sesuatu terjadi kita bisa pertanggung jawabkan ke depan”.

2. Melakukan tindakan untuk kebaikan, menghindari hal yang membahayakan

Prinsip ini merupakan pemahaman yang menyokong dalam tindakan keperawatan, karena area layanan keperawatan adalah manusia dengan kondisi yang memerlukan bantuan atau dalam kondisi menderita. Johnstone (1994), menyebutkan bahwa adalah tugas dari setiap insan untuk melakukan kebaikan kepada orang lain. Terkandung dalam prinsip ini adalah menghindari kemungkinan atau kerusakan melakukan tindakan yang diperlukan untuk menghindari kerugian, melakukan tindakan dengan kemungkinan tinggi mampu melindungi dari kerusakan, tindakan yang dilakukan tidak akan menimbulkan resiko, keuntungan yang didapat dari tindakan harus lebih besar dari pada kerugian atau biaya yang digunakan. Berikut penjelasan responden tersebut:

“..dalam pelaksaan keperawatan kita harus melaksanakn yang terbaik bagi pasien. Sebagai seorang perawat kita harus hati-hati melakukan tindakan sehingga jangan pasien merasa dirugikan misalnya sebelum dan sesudah melakukan indakan kita harus mencuci tangan untuk menghindari terjadinya infeksi dan kita menghindari infeksi penyakit pasien terhadap kita. Kalau pake jarum suntik sekali pakai buang jangan berulang-ulang, kalau memasang kateter harus dengan hati - hati jangan sampai terjadi infeksi pada saluran kemihnya, dan penyangga tempat tidur sudah rusak dan tidak layak pakai. Pasien disinikan rata-rata tidak sadar dan pada saat menscution jangan sampai 
kita jolok-jolok yang dapat menyebabkan iritasi kan merugikan pasien, dekubitus juga rajin kita miring-miringkan, jangan dia datang jadi dekubitus karna kita malas memiringkannya dan plebitis juga jangan terjadi, plebitis juga jangan infus sampai satu minggu atau dua minggu tidak kita ganti akhirnya dia demam".

\section{Agama mengajarkan berbuat baik}

Hal ini merupakan pemahaman yang dianut oleh responden, diman dari sudut pandang agama apapun, sumber agama merupakan daar dalam memberikan pelayanan kepada pasien, Hal itu berarti bahwa berbuat baik dianggap melaksanakan perintah Tuhan, dimana perintah tersebut dianggap sebagai moral yang baik dan benar. Sedangkan larangan Tuhan adalah sebagai hal yang salah dan buruk. Presepsi yang demikian mencerminkan pola berpikir yang berpedoman pada teori etika teologi yang merupakan teori dari deontologi klasik (Johstone, 1994). Pada dasarnya aturanaturan etis yang penting diterima oleh semua agama, maka pandangan moral yang dianut oleh agama-agama besar pada dasarnya hampir sama. Agama berisi topik-topik etis dan memberi motivasi serta inspirasi pada penganutnya untuk melaksanakan nilai-nilai dan norma-norma dngan penuh kepercayaan (Bartens, 2000). Berikut pernyataan respondensnya :

“..bila kita merawat pasien dengan cina dan kasih sayang itu merupakan bagian dari elayani sesama yang memerlukan pertolongan kita, dalam agama juga kita diajarkan kita sesama manusia harus tolong menolong, menghargai. Didalam ajaran agama muslim menolong sesama itu adalah ibadah, dan semua agama mengajarkan jadi kita menolong pasien dengan kasih ayang dan kita mendapat pahal kedepannya".

4. Tidak membeda-bedakan pasien dan mendahulukan tindakan sesuai prioritas masalah.

Prinsip tersebut merupakan prinsip perawat untuk memberikan pelayanan pa melakukan diskriminasi. Hal ini seseuai dengan prinsip menghargai individu sebagaimana adanya tanpa membedakan agama,suku,ras, bangsa dan sebagainya dan bersikap adil bagi semua psien yang menjadi tanggung jawabnya (Thompson, 2000). Dalam memberikan pelayan perawat tidak diskriminatif, melainkan memberiakn bantuan secara adil sesuai dengan keperluan pasien untuk mencapai derajat kesehatan yang optimum. Dalam konteks ini prinsip Ijustice (keadilan) diterapkan yaitu tidak membedabedakan pasien, dan memastikan pasien mendapatkan apa yang seharusnya didapatkan. Berikut pernyataan responden tersebut : “..dimana-mana memang kita harus berlaku adil, ya apalagi terhadap pasien, dalam merawat pasien kita tidak boleh. Saya merawat pasien itu sebagai seorang dengan memandang pasien itu orang yang betul-betul membutuhkan pertolongan, kita hormati pasien sebagai orang yang bermartabat yang sma dihadapan Tuhan yang sya sarankan seoerti saat ini dengan penggunaan jankesmas perawatan yag kita berikan sama dengan orang yang bisa bayar perawatan dengan penuh jadi kita tidsk boleh membeds-bedakannya

Mendahulukan tindakan sesuai dengan priorotas masalah .

Prinsip ini merupakan cara berpikir yang kritis, untuk memutuskan tindakan-tindakan yang penting, terutama yang mengancam jiwa, memerlukan penanganan yang segera untuk menyelamatkan pasien. Dengan cara berpikir yang demikian, maka dapat menyusun prioritas tindakan sesuai dengan prioritasmasalah, tentunya perawat jugamempertimbangkan tindakan untuk melakukan yang terbaik bagi pasien yang dirawatnya dengan memperhitungkan keuntungan bagi pasien (Johnstone, 1994).

Prinsip melakukan tindakan sesuai dengan prioritas masalah ini juga menekankan untuk bersikap adil terhadap pasien dengan tidak membedakan pasien berdasarkan status yang menyertainya, tetapi berdasarkan prioritas kebutuhan dari pasien. Dengan melakukan prioritas tindakan dengan tepat maka daat pula terdeteksi adanya suatu masalah lebih dini sehingga dapat mencegah terjadinya kondisi yng lebih buruk atau menghindari terjadinya hal yang membahayakannya. Berikut pernyataan responden tersebut :

“..dalam merawat pasien kita harus dapat membedakan dan memprioritaskan masalah maksudnya kita memprioritaskannya sesuai dengan kebutuhannya yang jelasnya penanganan yang emrgensi dulu itu intinya".

\section{Memberikan infrmasi dan mempertahankan kerahasiaan}

Prinsip ini merupakan prinsip confidentialy dan juga veracity dan ini harus dianut oleh perawat dimana perawat harus memberikan informasi yang lengkap dan mampu mempertahankan kerahasiaan pasien dalam hal-hal yang sudah ditentukan. Berikut penyampaian responden tersebut

"pastinya kita memberitahukan kelurga bahwa kondisi pasien sudah pada tahap terminal, imanapun kondisi pasien harus diberitahu karena kalau ada apa-apa kita juga nantinya yang disalahkan. Memang kita sebagai seorang perawat kita harus menjaga 
kerahasiaan pasien salah satunya tidak menceritakan kepada pasien dengan tidak menceritakan penyakit pasien kepada orang lain tentang apa penyakit pasien karena didalam sumpah perawat ada tertulis segala kerahasiaan pasien tidak boleh diceritakan kepada oarang lain kecuali deperlukan hukum”.

\section{Menghargai pasien atau keluarga yang} menggunakan cara-cara tradisional

Prinsip ini merupakan bagian dari prinsip mengahargai individu yang mempunyai kebebasan untuk menentukan diri sendiri. Dalam memberi kebebasan pasien ini, perawat memberikannya sebatas tidak menggangu pengobatan yang dilakukan oleh tim medis. Hal ini terjad karena dalam kontrak anatara pasien dengan rumah sakit, pasien menyerahkan pengobatan kepada tim medis. Oleh karena itu perawat sebagai anggota tim medis dalam memberikan pengobatan (Thompson, 2000). Menurut Johnstone (1994), yang termasuk budaya yang harus dihormati adalah kepercayaan, orientasi nilai, dan bagaimana orang memberi arti . dengan menghargai pasien atau keluarga menggunakan cara pengobatan tradisional , berarti kita juga bersikap menghormati pasien dalam menentukan diri sendiri, karena kita memberi kesempatan kepada pasien untuk melakukan apa yang diinginkan oleh pasien untuk melakukan ritual sesuai kepercayaannya, sejauh tidak menggangu proses pengobatan. Dengan menghormati budaya pasien itu juga diperlkan sikap menerima pasien apa adanya, sehingga meskipun perawat tidak sepaham dengan budaya pasien tetapi tetap menhghormatinya sbagai bagian dari diri pasien. Berikut pernyataan responden tersebut :

“.. kalau ada pasien atau keluarga yang meminta untuk menggunakan obat tradisional itu hak pasien. Jadi hak pasien untuk mempercayai obat tradisional, misalnya air yang diberi doa, kita tidak bisa menghalangi selama itu tidak menggangu perawatan dan terpi medis, itu boleh-boleh saja”.

\section{Simpulan dan Saran \\ Simpulan}

Faktor-faktor yang mempengaruhi presepsi adalah :

a. Intrinsik dan ekstrinsik seseorang (cara hidup, cara berfikir, kesiapaan mental,kebutuhan dan wawasan)

b. Faktor politik, ekonomi, sosial, budaya

c. Faktor usia

d. Faktor kematanagn

e. Faktor lingkungan sekitar f. Faktor pembawaan

g. Faktor fisik dan kesehatan

h. Faktor proses mental

Apabila dihubungkan antara teori dengan hasil yang didapatkan pada wawancara, hasilnya dominan sama dengan teori hal ini dipengaruhi oleh faktor usia yng tidak jauh beda (responden I usia 25 tahun, responden II usia 26 tahn, responden III usia 25 tahun dan responden IV usia 28 tahun ). Faktor lama bekerja di ICU (responden I lsm bekerja 4 tahun, responden III lama bekerja 5 tahun dan responden IV lama bekerja 4 1/2 tahun ).

\section{Saran}

Saran untuk rumah sakit untuk meningkatkan pelayanan kesehatan baik Bio-psiko-sosial-dan spiritual. Meningkatkan mutu pelayanan dan pemahaman perawat khususnya yang bertugas di ruang ICU.

\section{Daftar Pustaka}

Arikunto, (2005). Manajemen Penelitian. Jakarta: Rineka Cipta

Berger, (1999). Fundamental of Colaborating for optimal health. California: Appletion \& Lange

Bugin,B, (2003) Analisa Data penelitian kualitatif. Jakarta: Raja grafindo.

Djojodibroto, (1997). Kiat mengelola Rumah sakit. Jakarta: Hipocrates

Dorothy,Y, (1999). Dasar-dasar Riset Keperawatan. Edisi 2. Jakarta: EGC

Johnstone, (1994) Bioethics a nursing perspektif. Sydney: WB Saunders

K. Bertens, (1993) Etika. Jakarta: PT. Gramedia Utama

Lemeshow, (1997). Besar sampel dalam penelitian kesehatan. Yogyakarta: Gadjah Mada Universitas Press

Moeleong, (2000). Metodologi Penelitian Kualitatif. Bandung: PT Remaja Rosdakarya

Suhaemi, E, (2003). Etika Keperawatan: Aplikasi pada praktisi. Jakarta: EGC.

Soekidjo Notoadmojo, (2005). Metodologi Penelitian Kesehatan. Jakarta: PT. Rineka Cipta

Sri Lestari, (2004). Artikel Penelitian vol. 5 no. X. Bandung.

Suseno, (1987) Etika Dasar, masalah-masalah pokok filsafat. Yogyakarta: Kanisius

Tarmizi, T, (2003). Medical Ethics. Jakarta: PT. Gramedia Utama.

Thompson, (2000). Nursing Ethics. London: Churchill livingstone

Widayatun (1999) Ilmu Perilaku. Jakarta: PT. Gramedia Utama

Juanda Brahma (2008) Prinsip Etik, http://etika.blogspot.com, dibuka 26 April 2009 